\title{
Jóias do conhecimento
}

Um dos grandes desafios dos editores-chefes é propiciar a melhor qualidade de leitura possível no menor tempo. Assim, publicar um número excessivo de artigos marginalmente diferentes, ou de qualidade intermediária, significa transformar a leitura científica em um garimpo de informações. Esta situação inverte suas atribuições, pois, no processo da publicação científica, o leitor usa a "jóia do conhecimento", os revisores são ourives e o editor apenas garimpeiro.

O esforço contínuo da Revista em elevar os quilates do conhecimento publicado em suas páginas brilha, neste número, pela participação de novos revisores. Eles são fundamentais porque executam o trabalho árduo de polimento das submissões e sugestão de aceitação ou não dos artigos para publicação.

A Revista Dental Press de Ortodontia e Ortopedia Facial pratica, desde seu início, esse sistema de revisão pelos pares - ou peer review - dos artigos que serão publicados. As melhores revistas científicas também adotam esse método como sistema de análise, pois ele é o melhor disponível. Mas há outras práticas.

O sistema peer review está sendo contrastado por um projeto da Public Library of Science (PLoS), participante do movimento de acesso livre à informação. Sua revista científica, PLoS One, exclusivamente online, foi lançada em dezembro passado e publicará qualquer artigo que seja razoavelmente correto metodologicamente, após uma breve revisão para detectar falhas graves. $\mathrm{O}$ objetivo é publicar o artigo e deixar que os leitores analisem sua real qualidade. Ainda que a idéia de "publicar primeiro, julgar depois" possa parecer interessante em um primeiro momento, ela exibe pelo menos duas falhas importantes. A primeira é que o labor de peneirar as informações sai das mãos dos revisores e editores para as dos leitores. A segunda é que muitos estudantes e profissionais em formação ainda não dispõem dos filtros adequados para criticarem as informações publicadas.

Atualmente, a Revista Dental Press de Ortodontia e Ortopedia Facial caminha para uma taxa de aceitação para publicação de 30\% dos manuscritos submetidos. Assim, temos condição de selecionar trabalhos de excelente qualidade que, acreditamos, são de real interesse para os leitores. Entretanto, a não aceitação de um artigo nunca deve ser interpretada de forma negativa pelos autores. Particularmente, meu primeiro artigo foi reprovado pelo periódico para o qual o enviei. Tomei, na época, ao pé da letra a palavra. Reprovar tem vínculo etimológico com provar novamente, ter a chance de melhorar, em última análise - crescer. Após aprovações e reprovações, julgo que cresci mais com as últimas.

Por outro lado, a necessária aplicação de procedimentos de seleção cada vez mais rígidos enobrece os artigos escolhidos pela meritocracia. E o presente número é um bom exemplo disso.

A entrevista com o Prof. Luiz Gonzaga Gandini Jr. provê uma amostra interessante do vasto conhecimento que ele possui. Ao longo das respostas, ele trata de vários e diferentes assuntos - alguns deles abordados em artigos deste número - e mostra o porquê dele ser um expoente da Ortodontia internacional.

O impacto na oclusão da influência da queiloplastia realizada em tempo único e em dois tempos cirúrgicos em crianças com fissura bilateral completa de lábio e palato é analisado em um artigo de um dos maiores centros do mundo no tratamento de fissurados. Os resultados são interessantes.

Você já tratou com avanço de mandíbula um paciente ortocirúrgico que vivenciou uma reabsorção condilar progressiva, acarretando uma importante recidiva? Muitos de nossos colegas já, e eu também. A leitura na íntegra do trabalho de Liporaci Jr. et al. pode lhe ajudar a compreender os eventos relacionados a essa condição e, em certo grau, como evitá-la.

Quatro artigos que utilizaram a cefalometria como parte de sua metodologia têm assuntos encadeados. Eles tratam do dimorfismo sexual na face longa; das alterações verticais e ântero-posteriores na Classe II com uso de dois tipos de extrabucais, um deles de tração combinada - usado na face longa; o terceiro analisa o crescimento da base craniana em indivíduos com diferentes tipos de más oclusões; e o último da eficiência da barra palatina e, novamente, do extrabucal, na ancoragem durante a retração de dentes anteriores.

Rocha Filho et al. analisaram, por espectroscopia, o monômero residual em diferentes resinas acrílicas usadas em aparelhos ortodônticos. O assunto é relevante, dada a citotoxidade do monômero.

Dois artigos tratam de questões relacionadas à estabilidade do tratamento ortodôntico. Uma revisão da literatura lida com a estabilidade dos incisivos superiores, e um trabalho retrospectivo da distância intercaninos em pacientes tratados ortodonticamente.

A mordida aberta anterior é sempre um assunto interessante. Especialmente quando passamos a compreender como, no Rio Grande do Norte, fatores socioeconômicos impactam no estabelecimento dessa má oclusão.

Por fim, um assunto muito atual é explorado na seção Tópico Especial: a tomografia computadorizada de feixe cônico. O tema tem sido discutido nos principais congressos da Ortodontia e o uso da tomografia será cada vez mais freqüente no diagnóstico e tratamento de más oclusões complexas. Recomendo a todos a leitura desse artigo.

A garimpagem está concluída e a ourivesaria também. Eu lhes entrego com satisfação as jóias descritas. Elas certamente os enriquecerão - com sabedoria.

Desfrutem.

Jorge Faber

Editor 